\title{
Urban regeneration effects on industrial heritage and local community - Case study: Leeds, UK*
}

\section{Jasna Cizler}

\author{
PhD student at Faculty of Architecture, Department of Urban Studies, \\ University of Belgrade, Serbia \\ e-mail: cizlerj@gmail.com
}

\begin{abstract}
The paper examines the current policy, practices and the outcome of urban regeneration in Leeds, with a special focus on the industrial heritage of the city. It uses a critical and analytical problem-oriented approach. Due to its architectural, social, historical and technological significance, industrial heritage is a recognised factor of the identity of many cities today and is often associated with interests of the local community. As a former industrial city, Leeds has a number of unused industrial buildings and a lot of potential for developing on this base. Still, as the research shows, regeneration projects mostly focus on the promotion of commercial facilities and attempt to attract primarily tourists, students and young professionals to the city. Regeneration causes effects such as gentrification, lack of public facilities and the local community involvement and the loss of the sense of place. Some examples of alternative projects in Leeds are researched and different approaches to the city development suggested. A holistic and integral approach, oriented towards the needs of the local community is recognised as a possible direction for the future development.
\end{abstract}

Key words: urban regeneration, gentrification, local community, industrial heritage, Leeds.

* This paper is a result of the research carried out at School of Geography, University of Leeds, United Kingdom, from September 1st to November 28th, 2010. Financial support for research was provided by The British Scholarship Trust and is gratefully acknowledged. I am grateful to Paul Waley, Rachael Unsworth and David Bell who supervised my work at School of Geography, and to all of those who supported me in any respect during the completion of the project. 


\section{Introduction}

Many authors and documents tell about industrial heritage and its significance in cities today (Stratton, 2000.; TICCIH, 2003.; Edensor, 2005.; Mihajlov, 2009.). Due to its architectural, social, historical and technological significance, it could be an important factor in city's identity ${ }^{1}$ and can have a role in urban regeneration and serve as a catalyst for it.

Leeds has rich cultural and industrial heritage, and therefore a lot of potential for developing a strong image on this base. Still, the city tries to achieve distinctiveness and identity through selling and presenting itself as a centre for shopping and business, and through different iconic projects. Urban regeneration projects attract a lot of attention and a lot of money is being invested in them - while economically prosperous, this kind of development causes gentrification and it is not responding to major problems in the city, such as the gap between different social groups and continuous existence of deprived areas. Despite the fact that many regeneration projects have been awarded for its design, they have also been a topic of criticism and consequences can be seen in bad design, exclusiveness and lack of public facilities. Dominance of corporate-led development and private investments, and attempt to attract primarily tourists, students and young professionals to the city, result in achieving only partial success in addressing main city problems.

What happens with listed buildings and industrial architecture in this kind of system? Why not building on the existent values and getting the character and distinctiveness that city possesses into the offer? Very often, listed industrial buildings are preserved to a certain degree only in order to satisfy heritage regulations - the aim is to have them properly maintained and safeguarded, which often means just keeping the façade of the building and changing the rest. The problem is not only about the design of the valuable building itself, but about loosing the specific sense of place that former industrial areas have to offer. Possible role of industrial heritage in urban regeneration and its significance as a memory to local people are other topics connected with this. Arts and culture are often used in these spaces successfully, contributing to the city as a whole. In that way, industrial heritage is a tool for improving the city's image and generating stronger identity, being catalyst for urban regeneration and contributing to the local community and economy, as it is shown through many examples world-wide.

Is a different approach to urban regeneration needed if wanting to preserve "the sense of place", image and identity in Leeds? Some examples of alternative space uses can be seen in Leeds. If we talk about industrial heritage as an important factor for the community, identity and economy, is it possible that developing this kind of approach would contribute more to solving the crucial problems in the city?

1 "Identity is the extent to which a person can recognize or recall a place as being distinct from other places - as having a vivid, or unique, or at least a particular, character of its own" (Lynch, 1981.:131). 
This paper is a result of a research that aimed to examine current policy, practice and effects of regeneration of former industrial sites in Leeds, with focus on Holdback Urban Village project. It aims to examine the current policy regarding the industrial heritage and urban regeneration, to investigate the processes of bringing industrial sites back into use and to consider how these transformations affected a city. Research methods and techniques that were used are: case-study; overview of previous research, documents and literature; interviews with relevant stakeholders; and on-site data collection and observation.

\section{Leeds and its industrial heritage}

Leeds is one of the largest cities in England and the regional capital of Yorkshire and the Humber, with population of about 715.000 (2001 UK census). It is a service centre of the region for health-care, higher education, legal, financial and business services, and has a strategic position half way between London and Edinburgh. Origins of the city date back to before $11^{\text {th }}$ century. Until recently it was considered to be the archetypal northern industrial city. Wool and textile industry and international trade brought prosperity to the city in $18^{\text {th }}$ century and growth and prosperity began as a result of industry, when investments in covered markets and infrastructure started. The first woollen factory in the world was established in Leeds in 1790s. Industry started to become more and more diversified, with engineering, printing, pottery soap, tanning, shoe making, chemicals and clothing being added to the textile industry.

Aside from development, industry has brought major environmental problems to the city: derelict industrial buildings, contaminated land, large areas of poor quality housing and social problems. In $20^{\text {th }}$ century changes in economy caused changes in use of sites in central city area, with old industrial buildings being demolished or reused. Importance of manufacturing industries declined and they were replaced with consumer, financial and science industries. What has left was a significant number of valuable industrial buildings and there are now 30 listed buildings only within the Holbeck Urban Village today² (Percival, 2008.).

Nuttgens wrote that Leeds has an image problem as a place that is difficult to read and understand about three decades ago (Nuttgens, 1979.). Did anything much change since then? There are still few wholly positive images which the City Council feels able to use to depict the central area as being vibrant and lively urban environment (Smales, 1994.). City lacks distinctiveness, coherence and unifying strategy (Woroncow in Unsworth and Stillwell, 2008.). There is a lot of unrealized potential in the city, such as river Aire and historic buildings.

2 A listed building in the United Kingdom is a building that has been placed on the Statutory List of Buildings of Special Architectural or Historic Interest. There are three types of listed status: Grade I (buildings of exceptional interest, sometimes considered to be internationally important), Grade II* (particularly important buildings of more than special interest) and Grade II (buildings that are nationally important and of special interest). 
Many authors write about significance of heritage buildings and their relation to local community and identity of the space. Heyden and Castello (Heyden, 1995.; Castello, 2006.) emphasize significance of memory and history in people's perception of the space and creation of personal identity. English Heritage documents (English Heritage, 2004.; 2009.) look at historical surrounding as factor that gives people feeling of identity and tell about its importance in regeneration, since people define themselves and their identity through places where they live. Industrial heritage is a memory about the life of ordinary people and was an everyday surrounding for generations of workers, example of industrial progress, significant for its architecture, and as a local landmark (TICCIH, 2003.; Industrial heritage: the hidden face of European identity, 2004.). This could be particularly important in the time of globalization and homogenization of cultures, identities and spaces. Edensor (Edensor, 2005.) writes about alternative aesthetics of industrial ruins and its importance in over-designed modern cities where commercial influences dominate. He draws attention to various activities that take place in industrial ruins and warned about their eradication through policies that privilege homogenous new developments. Mihajlov also writes about significance of industrial heritage re-use and about how industrial heritage renewal can solve social problems in the city (Mihajlov, 2009.). A number of authors focus on adaptation and re-use of former industrial buildings as methods for improvement of space, creation of a place image, economic growth and promotion. Cities often aim to create their own specialty that can be promoted in order to achieve further benefits. Cities that have gone through industrial decline are enforced to create new options for economic growth and development, and identification of specialities such as industrial heritage, can have a positive effect. Still, as following chapters will show, though heritage is important factor for attracting investments, attention should be drawn on dominantly private-led, business friendly development as threatening factor.

\section{A critical analysis of regeneration of former industrial areas in Leeds - positive example of urban regeneration or missed opportunity?}

\subsection{UK regeneration policy and urban regeneration practice in Leeds}

From the 1990s more holistic approach to planning and development was adopted and a plan-led system of planning has operated since then. In 1999 Government made an Urban Task Force final report, Towards a Strong Urban Renaissance ${ }^{3}$, which was later carried forward into the Urban White Paper in 2000 by DETR ${ }^{4}$.

\footnotetext{
3 The Urban Task Force was faced with 3 specific urban challenges: decline of regional innercity areas and communities, an official prediction of a requirement for 4 million additional households, and suburban sprawl consuming greenfield sites, causing social and economic decline within inner-city areas.

${ }^{4}$ DETR (Department of the Environment, Transport and the Regions) operated until 2001 and after that replaced with DEFRA (Department for Environment, Food and Rural Affairs) and DTRL (Department for Transport, Local Government and Regions).
} 
These two documents on urban planning and development set agenda for an urban renaissance. The Government sets a national policy framework and provides a regulatory regime for local authorities for the treatment of the historic environment. Department for Culture, Media and Sport (DCMS) has responsibility for the identification, conservation and enhancement of the historic built environment in England. The Office of Deputy Prime Minister (ODPM) has responsibility for managing the environment through the planning and development control regime and a general role in promoting regeneration in deprived areas. English Heritage has a role to protect the historic environment and promote awareness and understanding of it.

Government planning policy is encouraging higher residential densities in new development whilst insisting nationally that at least 60 per cent of all new housing should be developed on previously developed land. It is hoped that this approach will address the shortfall in new housing, protect greenfield sites and create a more "European" style urbanism (Haughton, 2009.). It is important to draw attention to the link between derelict land and social deprivation. As Grubovic wrote (Grubovic, 2002.), majority of brownfield sites are inner-urban ex-industrial districts with large amounts of derelict land and buildings and they suffer from concentrated social deprivation. New programs, such as Urban Task Force (UTF), are not reconciled with programs concerned with social exclusion, and as such, they can even make gentrification" easier: "However, physical regeneration, which is offered by UTF is not enough. It must be supported by social and economic regeneration. Beside the good solutions, like mixed land use and creation of the pedestrian zones, UTF might create more problems, if it does not include social and economic dimension - like social exclusion and gentrification in British cities" (Grubovic, 2002.). Concepts of social inclusion and narrowing the gap are present in most official documents on Leeds development. One of Leeds City Council's main priorities is to narrow the gap between the most disadvantaged communities and the rest of Leeds.

24 Hour City Conference in 1993 articulated a vision for the city based on ideas of "European-ness" and city being the "Barcelona of the north", with 24 hour café society and city centre living. City centre living and living in new developments are promoted as an "urban idyll" - defined by Tallon (2010.) as idyllic city environment designed to attract middle-class gentrifiers. Holbeck, former industrial area of the city, today dominated by small-scale industrial units, is being re-branded as a Holbeck Urban Village (HUV). It is a multi-million pound regeneration programme that suppose to be an example of urban sustainability. The official planning framework for the area states that the aims of the redevelopment are to establish a new creative quarter; to strengthen Leeds' role as a regional business centre; to provide an employment; to deal with social exclusion; to improve the connection with the city

5 Gentrification is a process of physical, economic, social and cultural transformation of the area, resulting in an extension of the property system of the private ownership of domestic property, resettlement and possibly even marginalisation of former residents, by introducing individuals who share the same cultural lifestyle and consumer preferences. Its negative effects are mostly felt by the less well-off and displaced households and business (Tallon, 2010.). 
centre; to preserve the area's unique heritage; and to create a sustainable community with a distinctive sense of place (Leeds City Council 2006.; Holbeck Urban Village website, 2010.). Still, reality is often different than it was predicted and presented.

Holbeck Urban Village area is dominated by low value industrial uses from the post-war period, most of them being derelict. Historical monuments include Grade 1 listed Temple Works and the Grade 2 listed Tower Works, and much of the area is also covered by one of two conservation areas.

Granary Wharf is regenerated area of the HUV. Despite the rhetoric on preservation of heritage, only few historical buildings were left. Warehouse from 1777 is now used for offices and a restaurant. Neighbouring Round Foundry complex is a former engineering works built in 1795-1797 comprising of 7 listed buildings. The complex consists of $7,000 \mathrm{~m}^{2}$ of offices, apartments, restaurants, cafés, newsagent and a small art gallery. Redevelopment project won a number of architectural awards including: Best Creative Land Use and Best Urban Centre by Yorkshire Urban Renaissance Awards in 2005; Project of the Year by RICS Regeneration Awards in 2005; Excellence in Architecture and Built Environment and Best Commercial, Industrial and Retail by RIBA Yorkshire White Rose Awards in 2005. Across the road is a Marshall's Mill complex that consists of Grade II listed former flax spinning Marshall's mill and Marshall's court, built in 1791-1792 and used to employ over 2000 workers. Different architecture practices were commissioned to do the project in order to introduce diversity and make design that will evoke the materials used in the past. Future plans include a regeneration scheme utilising land around Marshalls Mill to create a new neighbourhood with a mix of residential, business space, offices, workshops, cafes, galleries and small local retail.

\subsection{Regeneration outcomes and local community issues}

Despite all the rhetoric in policy and many architectural awards gained, it could be seen that most of the project focuse on new comercial and residental facilities that are changing the social structure and habits of area inhabitants. "It is interesting to note that many gentrification proposals are claiming that they are constructing new public spaces" (Čaldarović and Šarinić, 2008.:376). Real public spaces are places "...where city life can easily be manifested and not scrutinized into pre-organized forms and schedules. Public spaces have their histories, their tradition, their own layers, they are full of memories of past generations and of existing people that remember past issues. Public spaces must be opened 24 hours in a day, they must be open for all citizens of a certain city or any kind of visitors" (Čaldarović and Šarinić, 2008.:376). As pictures show, this was not achieved in Leeds regeneration (Figures 1 and 2). 
Figures 1 and 2

Entrance zone of the redesigned Marshall's Mill: large parking area, walls and gates dominate the space, thus denying engagement and interaction with passers-by. There is a lack of services that attract people to come to the area, especially after the working hours
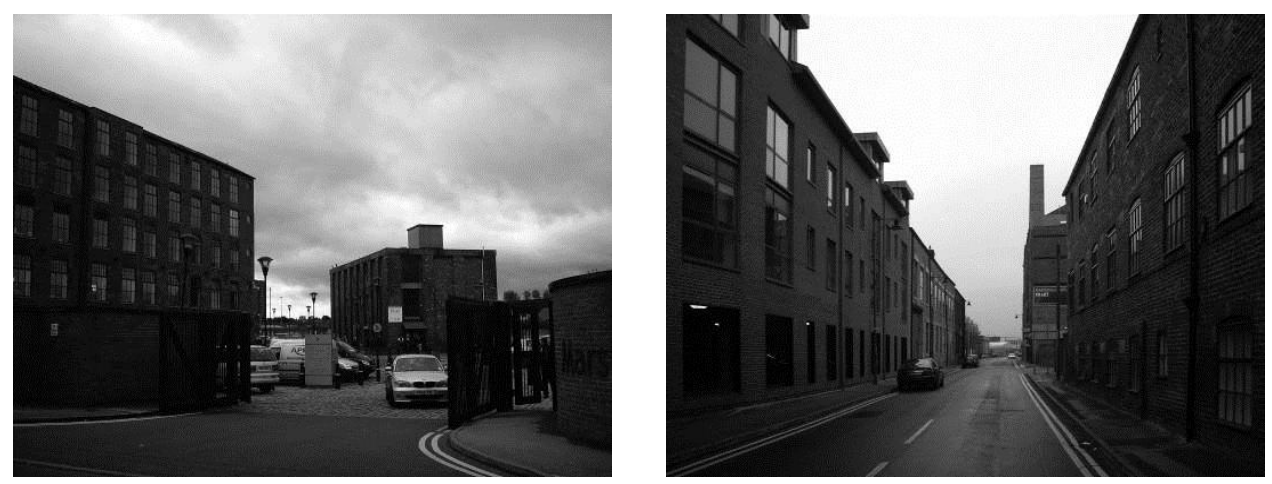

At the same time, "Job of selling places appears to be easier if there remains a semblance of historic continuity, especially if this sense of history" (Smales, 1994.). Industrial heritage is being used as a catalyst for promoting the space and for creating its image. It is similar when sustainability issues are concerned: “... at Tower Works I have observed 'the messy process of negotiation and deal making that underpins the business of actually getting buildings built on the site' (Evans, Jones, 2008.) and I have seen how sustainability is itself a story, or 'a grounded phenomenon, situated in place and performed by actors and institutions"' (Bell, 2009.).

Since regeneration in Leeds is mostly delivered through private sector, local authority is often under the pressure to accept the proposals that will generate most income. Government has little influence on the processes and absence of large-scale public sector involvement results in the lack of the coherence between projects and producing "islands in the city" (Figures 3 and 4). Another result of this is lack of places that do not generate the income, such as cultural facilities and public spaces (Unsworth and Smales, 2004.). At the same time, cultural policy, with its opportunistic and pragmatic approach (greater emphasis on cultural tourism and the pursuit of large-scale initiatives, than on community-oriented arts development), relates more to the needs of the tourist industry than to community regeneration (Strange, 1996.). As a result, some areas in the city centre are exclusively private-sector led. According to Chatterton and Hodkinson, this is a cause for concern considering that these are some of the last remaining central development sites and current schemes are based almost exclusively on high value city living apartments and offices for large firms (Chatterton and Hodkinson, 2007.a). This kind of schemes are entitled as "playground for tourists, students, wealthy and professional business class" and described as threatening to local context, activity and democratic control. Result is an increasingly corporate-owned city, with further consequences such as the loss of public assets, public and green space and limited social infrastructure ${ }^{6}$ (Chatter-

$\mathbf{6}$ Some sources indicate that no doctors' facilities or supermarkets have been provided for the 
ton and Hodkinson, 2007.a; 2007.b; Haughton, 2009.). On a larger scale this results with too expensive and elitist projects being adjacent to the back to back housing of poorer areas such as Holbeck and Beeston ${ }^{7}$. Urban scale of urban regeneration projects is very limited and boundaries are set by property boundaries.

Figures 3 and 4

Landscapes of contrast in Holbeck
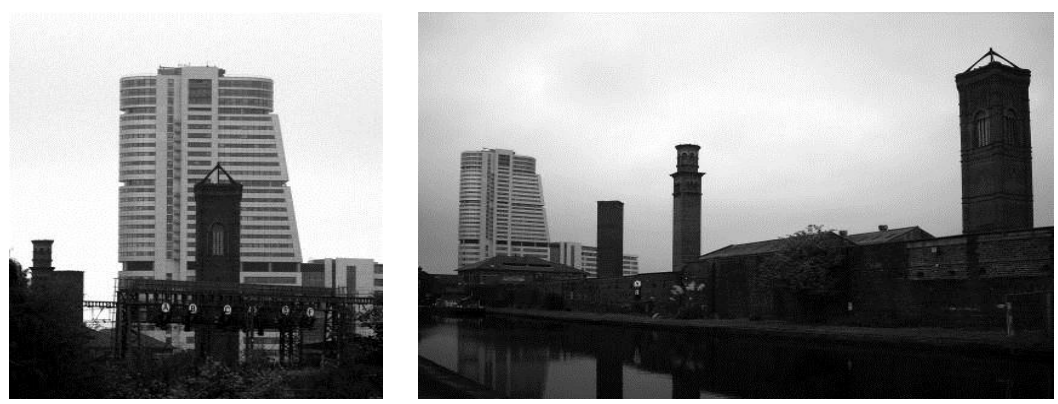

Regarding the design of the new projects on former industrial land, Haughton (2009.) expressed a lot of concern and critics saying that most apartments look the same and could be located in almost any city. He also writes on poor design, poor quality public space, inadequate provision of green space, badly sited residential blocks surrounded by busy and noisy roads, presenting a largely blank wall to the street, denying engagement and interaction with passers-by. Some even called them "the slums of the future" (architect Maxwell Hutchinson, 2006. in Haughton, 2009.).

Figure 5

Whose heritage? Whose open space? Victoria Quays neighbourhood with "PRIVATE RESIDENTS ONLY" sign and a chain on a pedestrian bridge. At the same time, Victoria Quays website offeres a different rhetoric: "A Haven in the Heart of the City" "Come and enjoy our friendly village atmosphere in wonderful surroundings..."

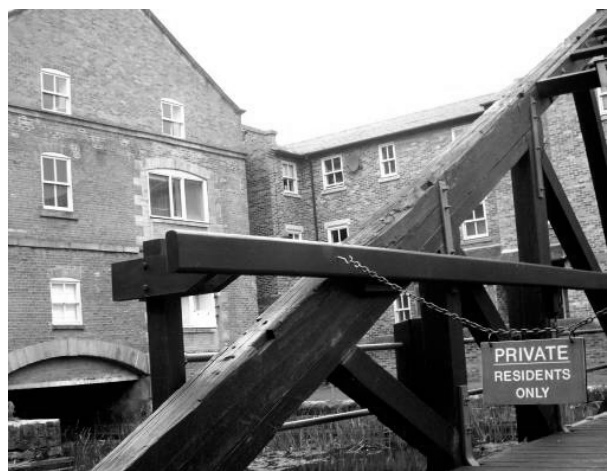

residents of the new area in Holbeck and that there is little provision for children and families.

${ }^{7}$ Social aspect of the regeneration and its effect on Beeston and Holbeck neighbourhoods is a topic of a "Ripples Out", a 45-minute documentary that explores the impact that regeneration had on poorer communities in Leeds. 
Gentrification is another phenomenon connected with urban regeneration projects in Leeds. Though one of City Council's priorities is to narrow the gap between the most disadvantaged communities and the rest of Leeds, with people forced out of their low cost rented homes, a gap seams only to grow. Instead of addressing problems and bringing affordable housing, number of exclusive, over-priced residential high-rise buildings grows and developers avoid building affordable homes8: “... house price increases force the poorer out of their own communities, and can displace them to cheaper parts of the city region...... This raises the moral issue - why should people be forced out of their low cost social rented home and forced into long-term debt to buy an expensive one?" (Chatterton and Hodkinson, 2007.b).

Privately-owned city centre sites bring to question local democracy and public control (Figure 5). After selling public services and property to global companies, less direct power of local representatives is left to respond to the urgent problems of the day such as climate change, social inequality and workers' rights (Chatterton and Hodkinson, 2007.b). Result is the loss of public assets and public space, and increasingly corporate-owned city. "One danger in the overlap of regeneration and gentrification is of producing very bland, monocultural developments, comprising young professionals without children housed in soulless, generic buildings. This may be the opposite of the policy rhetoric, but in the UK over the last decade, this kind of development has happened all too frequently" (Tallon, 2010.).

Another issue related to gentrification is a displacement of the original employment base as rents rise and owners are tempted to sell out or move. On the official HUV website there is information about improving connectivity and access to jobs for surrounding neighborhoods, but local jobs are simultaneously being displaced. "Workers on the low road' are actually the backbone of the Leeds economy — without them, the higher value jobs cannot function. The lack of affordable housing across the city and particularly in the more desirable green leafed suburban neighborhoods threatens economic growth... ... What we are seeing is the 'Brazilianisation' of the housing market, with key workers (increasingly migrants) commuting large distances from outlying towns such as Huddersfield and Dewsbury just to service, clean and run the essential components of Leeds' booming city centre economy (Chatterton and Hodkinson, 2007.b).

\section{Is a different approach possible?}

Smales and Powell wrote on commercialism, economic survival and ideas of Europeanness as threats to Leeds' development, and about necessity to look at city's

8 City's gap in affordable housing is one of the worst in UK and it is determined to demolish between 5,000 and 10,000 council homes over the next ten years as part of major regeneration programmes (Chatterton and Hodkinson, 2007.b).

9 Poverty pay, short-term, part-time jobs in the service, retail, leisure and catering sectors (Chatterton and Hodkinson, 2007.b). 
unique characteristics when planning its development sixteen years ago: "If there is a lesion to be learnt from Leeds, it is that the projects which appear to work best are those rooted in a clear understanding of a city's unique characteristics. Any attempt to create a re-vitalized image that is based upon superficial perceptions of what constitutes a "good European city" will inevitably lead to urban environments that are little more than a kit of badly assembled, dangerously fragile parts" (Powell, 1992. in Smales, 1994.). But, did Leeds have to set aside its past, history and heritage in the name of economic survival? A need to promote the city in an increasingly competitive market stands in contrast with the need to allow development of more community-based and alternative cultural activity ${ }^{10}$. It is obvious that different approach is needed if wanting relate to main problems in the city. There is a need for a more integrated, holistic and innovative approach, need for projects that enable ownership, allowing people to adapt spaces to new uses, to colonize and revitalize abandoned areas. Arts and other cultural disciplines should play more active role in urban regeneration. Heritage, cultural production and small scale business are unused potential for regenerating city life (Murray, 1999.).

Being critical towards the way city is developing, some local scholars have started a search for different, alternative approaches. Among these is Paul Chatterton, Reader at School of Geography at University of Leeds, who has worked with students and local people on Plan B for Leeds and creation of manifesto for the city, aimed to influence people to create fairer, equitable and sustainable future, through promoting public engagement. City wide network "Love It Share It" also explores new models for urban regeneration. Some examples of alternative space uses can be seen in HUV area. If we talk about industrial heritage as an important factor for the community and local identity, is it possible that developing this different approach would contribute more to solving the crucial problems in the city? More community sensible, art and culture, locally based projects probably would not provide more money at the first stage, but if they deal more and better with issues that concern the community, such as improvement of living conditions, public spaces and crime prevention, they might be more sustainable as the long-term option.

Temple works, a former mill, is privately owned, but used by a non-profit group which has through different projects brought artists and visitors into unused building. This is a Grade I listed building - one of only eight such buildings in central Leeds. Since late 2009 it hosts different arts and culture events. Having a "buy nothing policy", all practical work to repair the building is done by volunteers or artists, and old and second handed furniture is being used. At the same time, this is the case when building that was privately owned throughout the history became a public good $^{11}$ due to its significance and meaning for local people (cultural, aesthetic, social, historical, etc.) Production of public goods is today a multi-actor activity in

10 Cultural policy with its opportunistic and pragmatic approach, relates more to the needs of the tourist industry than to community regeneration (Strange, 1996.).

11 Artefacts and values that are collectively used and available to large number of users; they are non-rival and non-excludable. 
which state, civil sector, private investors and other relevant actors should be equaly engaged, and partnership and transparency in decision making are main means of protecting public good and interests of actors (Petovar and Vujošević, 2008.:43-44).

\section{Conclusion}

This paper is a result of research of the current policy, practice and effects of regeneration of former industrial sites in Leeds. Critical overview of the current issues in Leeds' development, such as lack of places that do not generate the income, dominance of commercial projects and gentrification, has shown some general problems in the city. These issues are also the main topics when it comes to industrial heritage and is use.

It seems that Leeds is missing the opportunity to generate its identity from the past while trying to build the new image and identity. As it was shown in the paper, Leeds has a rich cultural and industrial heritage, and therefore a lot of potential for developing the strong image on this base. But, instead of building on the existent values and getting the character and varieties that city possesses into the offer, it tries to achieve distinctiveness through presenting itself as a centre for shopping and business, and through different iconic projects led by market forces. It is shown that dominance of corporate-led development, commercial and private investments results in achieving only partial success in regenerating the city and saving its heritage. Potentials such as waterfront and historic buildings are unrealized and the city lacks distinctiveness and coherence.

There is no doubt that Leeds has been regenerated, and that most of the areas are now in better state than few decades ago. Bad reputation and the perception of industrial cities and areas such as Holbeck have changed. Still, new activities and ways of life that have transformed them are questionable, and the real question is, as Haughton (2009.) said, for whom, for whose tastes for whose profit this happened, and why to such a poor effect in terms of quality of life?

It is shown that heritage is an important factor for attracting the investments, but attempt was made in drawing the attention on dominantly private-led, business friendly development as threatening factor when dealing with it. One of the crucial questions about this is how can we deal with preservation of heritage for the local people when architecture and cities are to such a big extent dependant on and led by market tools? Heritage and especially industrial buildings have in recent decades become not only a tool for promotion of certain image and conservation of memory of industrial past, but also a marketing tool used to sell places under higher prices. Marketing strategies and their role in urban regeneration and heritage use, could be an interesting topic for future research, especially in Leeds and other UK cities where market has such a big role in development.

As this paper has shown, there is a need for a more integrated and holistic approach to planning and development in Leeds. Also, this paper tried to indicate the significance of small scale, more innovative, community led projects that enable adapta- 
tion of spaces to new uses by local people themselves. This kind of projects, as well as arts and culture, should play bigger role in urban regeneration and management of heritage.

\section{Literature}

1. Bell, D. (2009). Re-Placing Stories, Re-Storying Places. Presentation held in Munster, Germany.

2. Castello, L. (2006). City \& Time and Places: Bridging the Concept of Place to Urban Conservation Planning. City E Time, vol. 2.

3. Chatterton, P. and Hodkinson, S. (2007a). Leeds Skyscraper City. The Yorkshire and Humber Regional Review, spring 2007.

4. Chatterton, P. and Hodkinson, S. (2007b). Leeds Sustainable City. The Yorkshire and Humber Regional Review, summer 2007.

5. Čaldarović, O. and Šarinić, J. (2008). First signs of gentrification? Urban regeneration in the transitional society: the case of Croatia. Sociologija i prostor, 181/182 (3/4): 369-381.

6. Edensor, T. (2005). Industrial Ruins: Spaces, Aesthetics and Materiality. Oxford: Berg Publishers.

7. English Heritage (2009). Heritage-Based Regeneration. English Heritage.

8. English Heritage (2004). People and Places: A Response to Government and the Value of Culture. English Heritage.

9. Evans, J. and Jones, P. (2008). Rethinking sustainable urban regeneration: ambiguity, creativity, and the shared territory. Environment \& Planning, A 40: 14161434 .

10. Grubovic, Lj. (2002). Urban Task Force. SPATIUM International Review, 8: 37-40.

11. Haughton, G. (2009). Celebrating Leeds. The Yorkshire and Humber Regional Review, winter 2009.

12. Hayden, D. (1995). The Power of Place: Urban Landscapes as Public History. Cambridge: MIT Press.

13. Holbeck Urban Village official website. Accessed 30 ${ }^{\text {th }}$ October 2010 (www.holbeckurbanvillage.co.uk/).

14. Jones, P., and Evans, J. (2008). Urban Regeneration in the UK. London: SAGE Publications.

15. Leeds City Council (2006). Holbeck Urban Village (HUV) Revised Planning Framework. Leeds: Leeds City Council.

16. Lynch, K. (1981). Good City Form. Cambridge: MIT Press.

17. Mihajlov, V. (2009). Industrial heritage renewal - social motives and effects. Sociologija i prostor, 184 (2): 139-164.

18. Murray, C. (1999). Rethinking Neighbourhoods: From Urban Villages to Cultural Hubs, in: Bell, D. and Jayne, M. (Eds.). (2004). City of Quarters: Urban Villages in the Contemporary City. Aldershot: Ashgate.

19. Nuttgens, P. (1979). Leeds: The Back to Front, Inside Out, Upside Down City. Otley: Stile Books.

20. Percival, T. (2008). 'Urban renaissance' or gentrification?: a critical analysis of urban change in Holbeck, Leeds. Leeds: University of Leeds, School of Geography. 
21. Petovar, K. and Vujošević, M. (2008). Public interest and public benefit in urban and spatial planning. Sociologija i prostor, 179 (1): 23-51.

22. Smales, L. (1994). Desperate pragmatism or shrewd optimism? The image and selling of West Yorkshire, in: Haughton, G. and Whitney, D. (Eds.). Reinventing a Region: Restructuring in West Yorkshire. Avebury: Ashgate Publishing.

23. Strange, I. (1996). Pragmatism, opportunity and entertainment: The arts, culture and urban economic regeneration in Leeds, in: Haughton, G. and Williams, C. (Eds.). Corporate City: Partnership, Participation and Partition in Urban Development in Leeds. Aldershot: Ashgate.

24. Stratton, M. (Ed.) (2000). Industrial Buildings: Conservation and Regeneration. London, New York: Taylor and Francis.

25. Tallon, A. (2010). Urban Regeneration in the UK. Oxon: Routledge.

26. Unsworth, R. and Smales, L. (2010). Leeds, Shaping Change and Guiding Success, in: Putner, J. (Ed.). Urban Design and the British Urban Renaissance. Oxon: Routledge.

27. Unsworth, R. and Stillwell, J. (2008). Around Leeds: a City Centre Reinvented. Leeds: Leeds University Press.

28. Unsworth, R. and Smales, L. (2004). Form, Movement, Space and Use: Land-Use Planning and Urban Design, in: Unsworth, R. and Stillwell, J. (Eds.). Twenty-first Century Leeds: Geographies of a Regional City. Leeds: Leeds University Press.

29. TICCIH (2003). The Nizhny Tagil Charter for the Industrial Heritage. Accessed 30th October 2010 (www.mnactec.cat/ticcih/industrial_heritage.htm).

30. (2004). Industrial heritage: the hidden face of European identity. INTERREG IVB North-West Europe Programme Newsletter, n 4. 
Jasna Cizler

Arhitektonski fakultet, Departman za urbanizam,

Univerzitet u Beogradu, Srbija

e-mail: cizlerj@gmail.com

\title{
Utjecaj urbane regeneracije na industrijsko nasljeđe i lokalnu zajednicu - Studija slučaja: Leeds, UK
}

\begin{abstract}
Sažetak
U radu se ispituju tekuća politika, praksa i rezultati urbane regeneracije u Leedsu, s posebnim naglaskom na industrijskoj baštini grada. Ovo je pregledni rad s kritičkim i analitičkim pristupom orijentiranim na problem. Zbog svog arhitektonskog, socijalnog, povijesnog i tehnološkog značaja, industrijska baština je prepoznata kao značajna u identitetu mnogih gradova i danas je često povezana s interesima lokalne zajednice. Kao bivši industrijski grad, Leeds ima niz neiskorištenih industrijskih zgrada i mnogo potencijala za razvoj na toj bazi. Ipak, kao što je istraživanje pokazalo, projekti regeneracije se fokusiraju na poticanje komercijalnih funkcija, te se u grad pokušavaju privući prvenstveno turisti, studenti i mladi profesionalci. Regeneracija uzrokuje gentrifikaciju, nedostatak javnih objekata i angažmana lokalne zajednice, kao i gubitak karaktera prostora. Neki primjeri alternativnih projekata u Leedsu su istraženi i predloženi su mogući drugačiji pristupi razvoju grada. Holistički i integralni pristup, orijentiran prema potrebama lokalne zajednice je prepoznat kao mogući pravac u kom bi se razvoj trebao kretati.
\end{abstract}

Ključne riječi: urbana regeneracija, gentrifikacija, lokalna zajednica, industrijska baština, Leeds. 